\title{
AMAUROASCUS KUEHNII AND OTHER FUNGI ISOLATED FROM A DEER HORN IN POLAND
}

\author{
Andrzej Chlebicki \& Wojciech Spisak
}

\begin{abstract}
Four keratinophilic fungi isolated from deer horn collected in Gorce National Park (Poland) are reported: Amauroascus kuehnii Arx with its malbranchea-like anamorph, Isaria fumosorosea Wize, Mortierella elongata Linnem., and Penicillium spinulosum Thom s.l. The record of Amauroascus kuehnii is its second locality in Europe, and keratin deer horn is a new substrate for this fungus.
\end{abstract}

Key words: Amauroascus, ascomycete, dermatophilic fungi, distribution, Malbranchea, mitosporic and anamorphic fungi

Andrzej Chlebicki, W. Szafer Institute of Botany, Polish Academy of Sciences, Lubicz 46, 31-512 Kraków, Poland; e-mail: a.chlebicki@botany.pl

Wojciech Spisak, Research \& Development Centre „Alcor” Ltd, Keppska 12, 45-130 Opole, Poland; e-mail: spisak@alcor.pl

\section{INTRODUCTION}

Soil is a reservoir of diverse symbiotic, saprobic and pathogenic fungi, including dermatophytes. That latter group is characterized by the ability to produce proteolytic and keratinolytic enzymes capable of decomposing various keratinized structures such as hair, horn, feathers, wool, bone, hoof, claws and cornified (keratinized) epidermis (Otčenašek et al. 1967; Garg et al. 1985; Wawrzkiewicz et al. 1987). They can infect animals, which are the source of secondary infection to man (Ajello 1974), and some can produce antibiotics (Uri et al. 1957; Wrigth 1956).

Decomposition of keratin into proteins results in alkalization (Faterpekar et al. 2008). Animal horns are sometimes colonized by specific fungi of the genus Onygena Pers., such as $O$. corvina Alb. \& Schwein. and $O$. equina (Willd.) Pers. (Hansen 1998). These species have been reported from several localities in Poland (Gumińska 1977; Komorowska 1986). They belong to the keratinolytic fungi sensu Hubálek (2000): that is, keratin-decomposing fungi. Other fungi can grow on keratinized tissues but are not able to decompose keratin. Here we report four fungi isolated from a deer horn collected in Gorce National Park, Poland, including the very rare species Amauroascus kuehnii Arx reported previously only from a few stations in North America and Europe.

\section{MATERIAL AND METHODS}

The fungi were extracted from deer horn with a sterile scalpel and then grown on MEA and PDA media in Petri dishes. The inoculated media were incubated at $16^{\circ} \mathrm{C}$ in the dark. Dibromothymolsulfonophtalein (bromothymol blue) was used to indicate the $\mathrm{pH}$ of the fungal products diffused into the medium: 10 drops of pigment solution and 10 drops of $10 \% \mathrm{KOH}$ were added to $250 \mathrm{ml} \mathrm{PDA}$ at $80^{\circ} \mathrm{C}$. This indicator changes the medium color depending on $\mathrm{pH}$ : green for the neutral range, yellow for slightly acidic, and blue for slightly basic. The morphological characters of the living fungi were examined in water and Lactophenol Cotton Blue by light microscopy (Nikon SMZ 1500, Nikon Labophot 2, Nikon Eclipse 800). Micrographs were taken with these microscopes fitted with a digital camera. For scanning electron microscope (SEM) studies, mycelium was fixed in $3 \%$ buffered glutaraldehyde ( $\mathrm{pH} 7$ ), washed twice in buffer for $10 \mathrm{~min}$ and dehydrated in ETOH (ethanol) and acetone, coated with gold and photographed using a LEO 1430 VP Zeiss microscope with a working distance of $c a 10 \mathrm{~mm}$. 


\section{RESULTS AND DISCUSSION}

Four species of fungi were isolated from the deer horn. Only one of them (Amauroascus kuehnii) is a keratinolytic species. The other three keratinophilic fungi (Isaria fumosorosea, Mortierella elongata, Penicillium spinulosum) cannot decompose keratin.

\section{Amauroascus kuehnii Arx}

Persoonia 6(3): 373. 1971. - Auxarthron kuehnii (Arx) M. Solé, Cano, Guarro, Mycol. Res. 106: 388. 2002.

TELEOMORPH. Ascomata gymnothecial, globose (Fig. 1A, B), pale yellow, superficial, solitary or rarely confluent, without distinct peridial elements, peridial hyphae thin-walled, pale brown, septate, encrusted with pigmented granules, branched, tips blunt, asci saccate, $(14-) 15-17 \times 9.5-11.5 \mu \mathrm{m}$, ascospores globose, alveolate, reticulate with raised bands and \pm oval meshes with undulating surface, 4-5 $\mu \mathrm{m}$ diam. (Fig. 1D, E \& 2), ca 13 bands per ascospore diameter.

ANAMORPH (malbranchea-like). Colonies on PDA at $18^{\circ} \mathrm{C}$ reaching $68 \mathrm{~mm}$ in 24 days, white on whole surface, aerial mycelium cottony, ca $2 \mathrm{~mm}$ high, after month ca $6 \mathrm{~mm}$ high (Fig. 4A), with small umbo in center, pale yellow droplets of exudates appear after two weeks, white sectors of dense mycelium present (Fig. 1C), reverse white to pale yellow (as color of medium), margin regular. Hyphae bearing lateral fertile branches straight, arthroconidia hyaline, cylindrical with truncate ends 3.7-4.3 × 2.5-3.1 $\mu \mathrm{m}$ (Fig. 3). Strain growing on PDA medium with dibromothymolsulfonophtalein
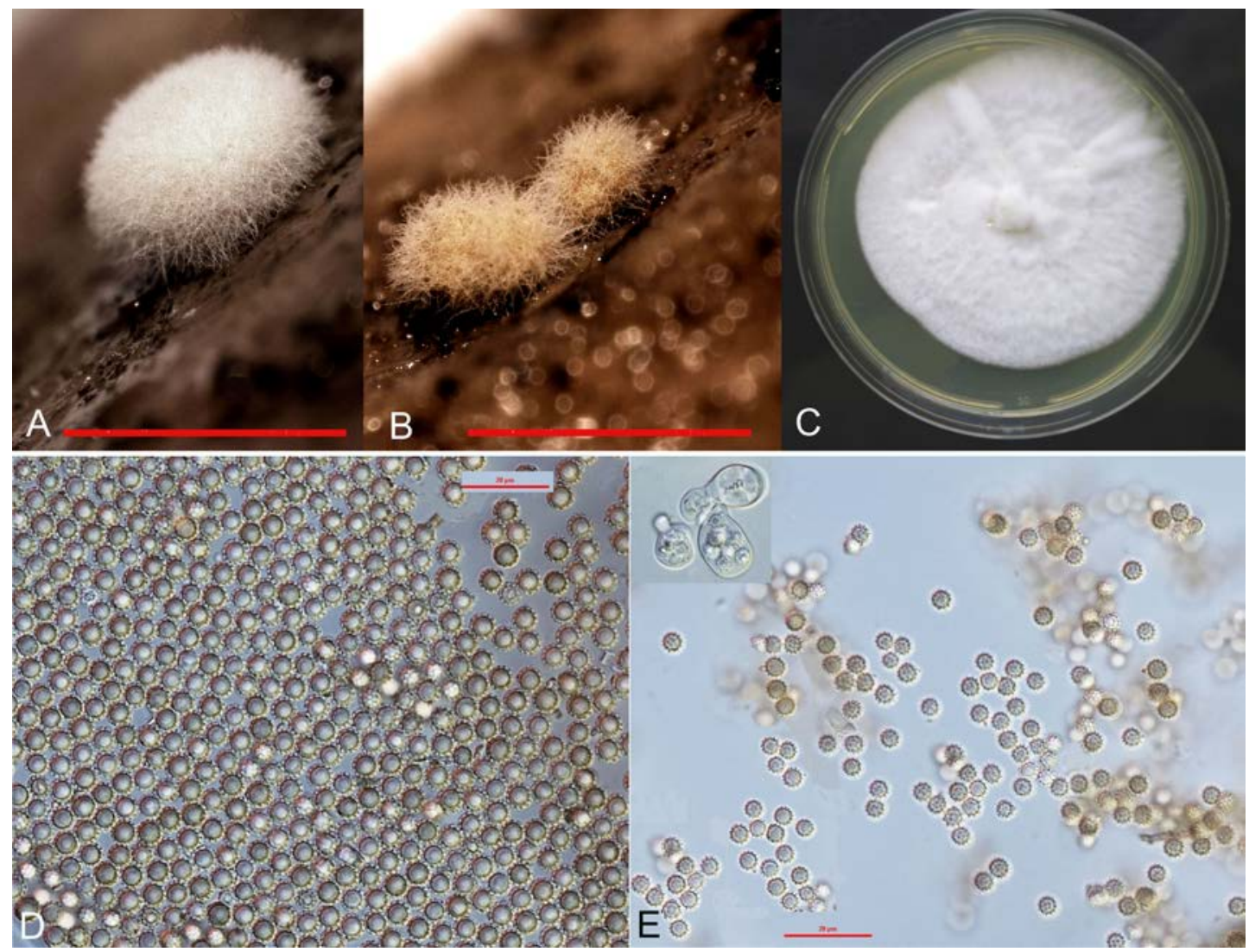

Fig. 1. Amauroascus kuehnii Arx: A - adult ascoma (scale bar $=1 \mathrm{~mm}), \mathrm{B}$ - young ascomata (scale bar $=1 \mathrm{~mm})$, C - colony on PDA after 24 days at $16^{\circ} \mathrm{C}$ in the dark, obverse, D - ascospores (LM), E - asci and ascospores (LM). 


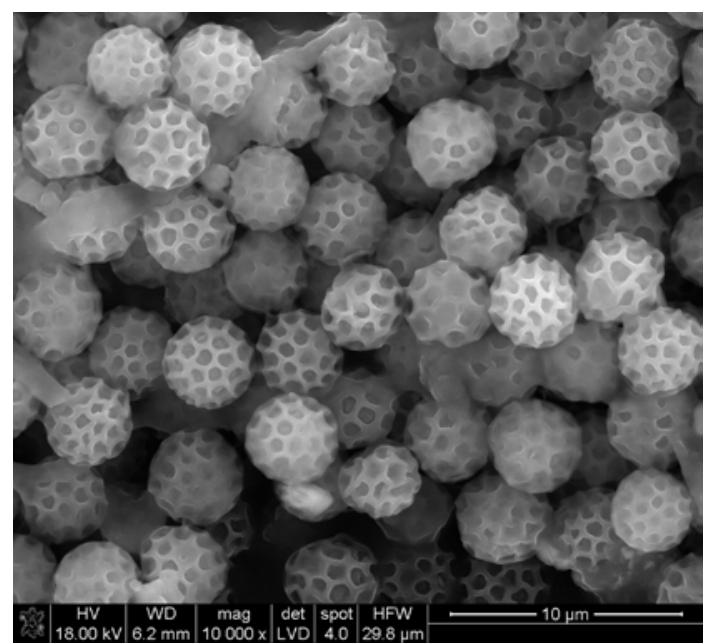

Fig. 2. Amauroascus kuehnii Arx, ascospores with thick bands and oval meshes (SEM).

as $\mathrm{pH}$ indicator did not show any change in color of medium, meaning that this strain not diffuse acidic products to the medium.

Material examined: POLAND, Carpathians, Gorce National Park, 49 $34^{\prime} 20^{\prime \prime} \mathrm{N}, 20^{\circ} 12^{\prime} 10^{\prime \prime} \mathrm{E}$, in spruce forest, on deer horn wedged in soil, 25 July 2014, leg. A. Chlebicki (KRAM F 58021; malbranchea-like anamorph, strain PGH-24, deposited in KRAM F).

Notes. The collected deer horn, preserved in a very damp container at room temperature (day/ night) was first overgrown by white colonies of the malbranchea-like anamorph. The ascomata of Amauroascus kuehnii appeared after 3 months of storage. Amauroascus kuehnii is a rare fungus in North America and Europe. Kuehn (1957) noted it on bat dung in Georgia, United States. Currah (1985) reported its occurrence on lizard and mouse dung in the USA. Cano et al. (1987) isolated it from soil in Spain, and Guarro et al. (2012) reported it from Mexico. Keratin deer horn is a new substrate for this fungus.

Amauroascus J. Schröt. is related to Auxarthron G. F. Orr \& Kuehn, and the distinction between these two genera has been suggested to be unclear (Currah 1985). Members of the genus Auxarthron have differentiated peridial hyphae and smaller punctae on the ascospore walls. Well developed reticuloperidia of ascospores of the genus $\mathrm{Au}$ - xarthron are easily distinguished from those of Amauroascus (Sugiyama et al. 2002). According to Solé et al. (2002b) Auxarthron is a monophyletic genus while Amauroascus is clearly polyphyletic. Sugiyama et al. (2002) noted that Amauroascus is split into two lineages, but stated that the genera Amauroascus and Auxarthron are separate. Amauroascus kuehnii is morphologically intermediate between these two genera (Currah 1985). It has reticulate ascospores but does not have clearly differentiated peridial hyphae (Solé et al. 2002a). Solé et al. (2002b) recombined the species to the genus Auxarthron. Here we consider the species to be a member of the genus Amauroascus.

Index Fungorum (www.indexfungorum.org) listed 15 species as accepted in the genus Amauroascus J. Schröt. Three of these species were previously reported from Poland: Schröter (1893) described $A$. niger J. Schröt. and noted $A$. aureus (Eidam) Arx, and A. mutatus (Quél.) Rammeloo (as A. verrucosus Eidam). Amauroascus kuehnii is new for Poland.

The anamorphs of Amauroascus were assigned to the genera Chrysosporium Corda and Malbranchea Sacc. Previously several Chrysosporium species as well as Malbranchea pulchella Sacc. \& Penz. were reported from Poland (Mułenko et al. 2008). Malbranchea pulchella, noted in Poland by Gładoch (1978), is the anamorph of Myxotrichum Kunze. It has tightly coiled fertile branches which later disarticulate into conidia.

\section{Isaria fumosorosea Wize}

Bull. Int. Acad. Sci. Lett. Cracovie, Cl. Sci. Math. Nat. Sér. B (1904): 721. 1904. - Paecilomyces fumosoroseus (Wize) A. H. S. Br. \& G. Sm., Trans. Br. Mycol. Soc. 40: 67. 1957.

Mycelium flat, reddish-white (Fig. 4C), hyphae hyaline 3.0-3.5 $\mu \mathrm{m}$ wide, phialides smooth-walled, 5.0-6.5 $\times 2.5-3.0) \mu \mathrm{m}$, conidia ovoid, smoothwalled, $3.0 \times 1.5-2.0 \mu \mathrm{m}$.

Material examined: POLAND, Carpathians, Gorce National Park, $49^{\circ} 34^{\prime} 20^{\prime \prime} \mathrm{N}, 20^{\circ} 12^{\prime} 10^{\prime \prime} \mathrm{E}$, in spruce forest, on deer horn wedged in soil, 25 July 2014, leg. A. Chlebicki (strain PGH-22 deposited in KRAM F).

Notes. Isaria fumosorosea occurs on plant debris, soil and insects at many localities in Poland 


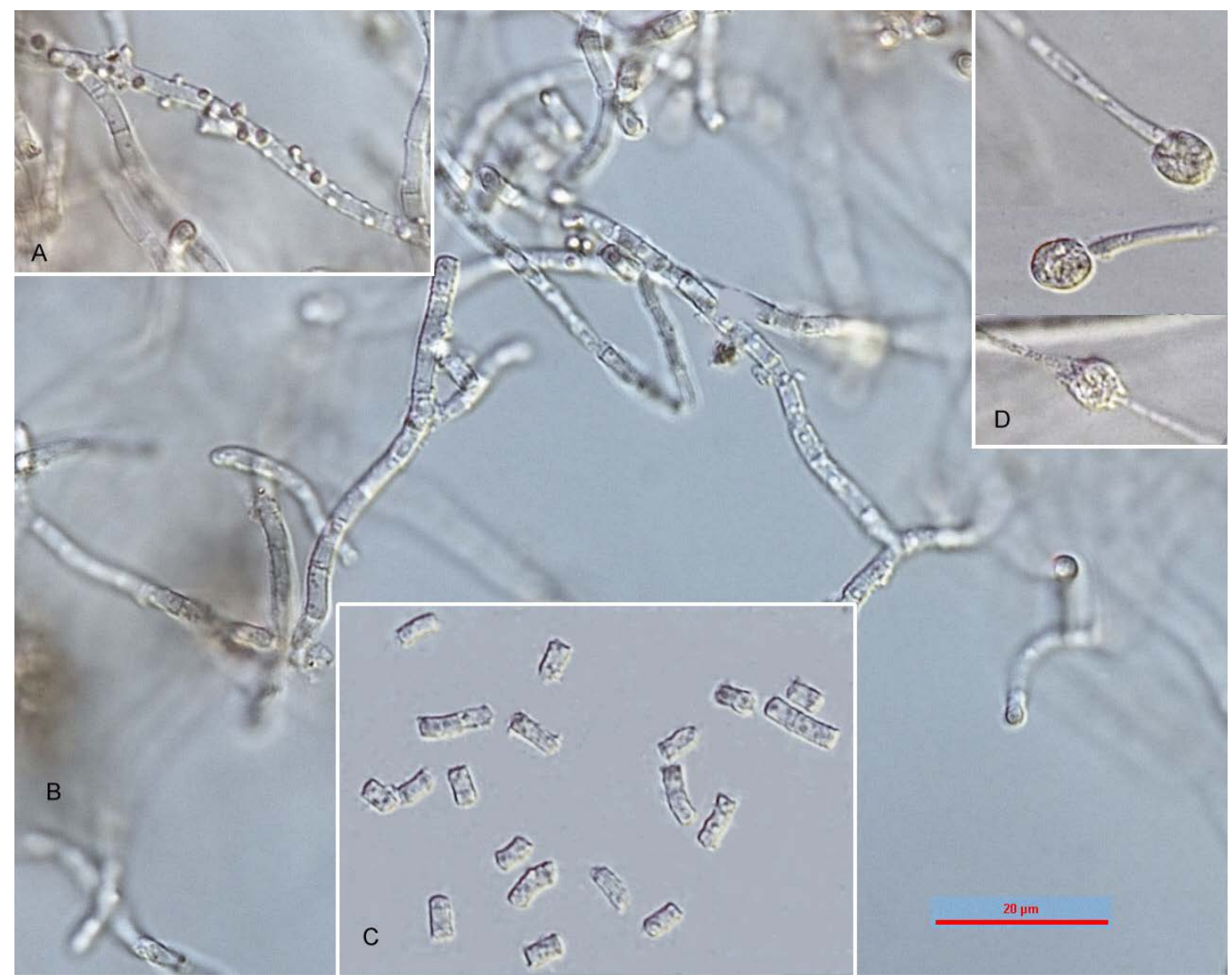

Fig. 3. Malbranchea-like anamorph of Amauroascus kuehnii Arx: A - verruculose hyphae, B - septate and branched hyphae, C - arthroconidia, D - small "bulbs" attached to hyphae (top and intercalary position), probably bacteria. Photo A. Chlebicki.

(Kozak 2008, as Paecilomyces fumosoroseus). In view of the high morphological variability of the taxon it should be recognized as a species complex rather than a single species (Zimmerman 2008). Isaria fumosorosea is a well known entomopathogenic fungus (Xia et al. 2013).

\section{Mortierella elongata Linnem.}

Mucor.-Gatt. Mortierella Coem. 23: 21. 1941.

Material examined: POland, Carpathians, Gorce National Park, $49^{\circ} 34^{\prime} 20^{\prime \prime} \mathrm{N}, 20^{\circ} 12^{\prime} 10^{\prime \prime} \mathrm{E}$, in spruce forest, on deer horn wedged in soil, 25 July 2014, leg. A. Chlebicki (strain not preserved).

Notes. Mortierella elongata was noted in Poland by Badurowa and Badura (1967), Dorenda (1986), Mańka et al. (1987) and Chlebicki et al.
(2014). It is a well known soil fungus also noted as a bacterial endosymbiont (Dematheis et al. 2012).

\section{Penicillium spinulosum Thom s.l.}

Bull. Bur. Animal Industr. U.S.D.A. 118: 76. 1910. Penicillim trzebinskii K. M. Zaleski, Bull. Acad. Polon. Sci., Math. et Nat., Sér. B (1927): 498. 1927.

Material examined: POland, Carpathians, Gorce National Park, $49^{\circ} 34^{\prime} 20^{\prime \prime} \mathrm{N}, 20^{\circ} 12^{\prime} 10^{\prime \prime} \mathrm{E}$, in spruce forest, on deer horn wedged in soil, 25 July 2014, leg. A. Chlebicki (strain PGH-23, deposited in KRAM F).

Notes. This species belongs to the Penicillium spinulosum clade, section Aspergilloides sensu Houbraken et al. (2014). Our strain is characterized by its monoverticillate penicillia with occasionally branched stipes, yellow exudates and slightly orna- 

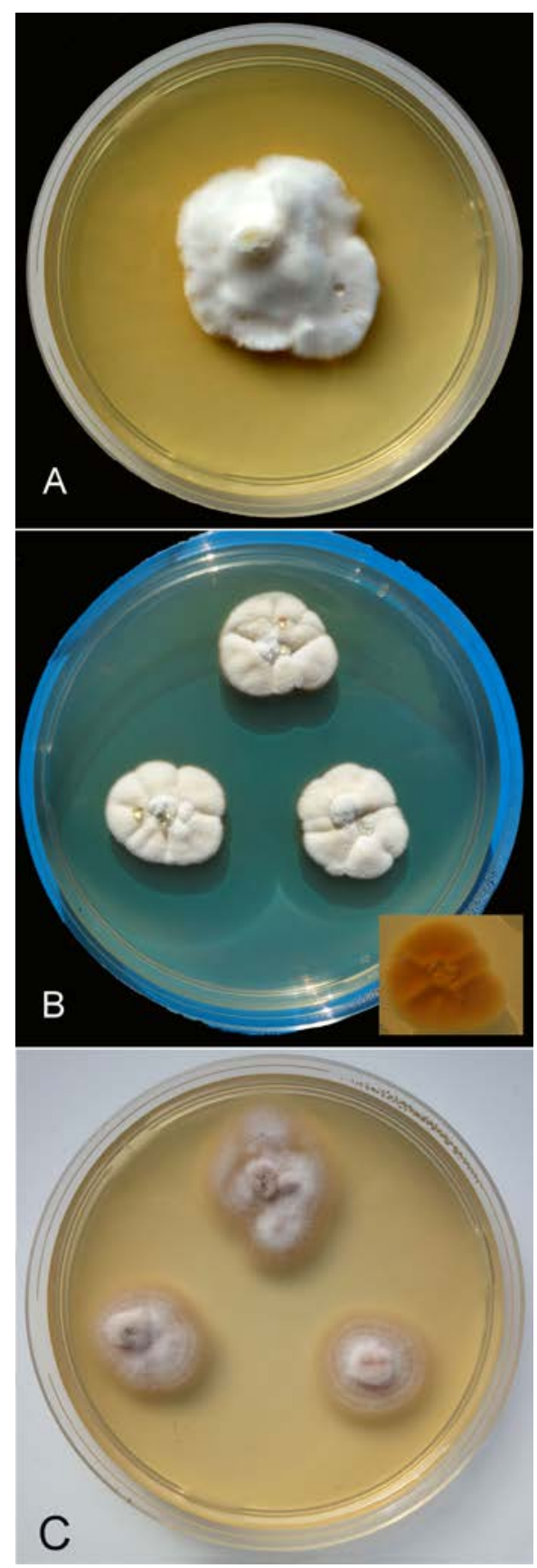

Fig. 4. Malbranchea-like anamorph: A - colony on PDA after 2 months at $16^{\circ} \mathrm{C}$ in the dark, obverse. Penicillium spinulosum Thom: $\mathrm{B}$ - colonies on MEA after 10 days at room temperature, obverse and single reverse, day/night. Isaria fumosorosea Wize: $\mathrm{C}$ - culture on MEA after 10 days at room temperature, obverse, day/night (all Petri plates $90 \mathrm{~mm}$ diam.). Photo A. Chlebicki. mented conidia. Colonies on PDA were gray, with an orange-brown to dark brown reverse. Colonies on MEA were white-rose to pale gray, with a pale brown reverse (Fig. 4B). Penicillium spinulosum has frequently been isolated from the rhizosphere and soil in Poland (Świderska-Burek \& Mamczarz 2008). The fungus was also the species most frequently isolated from wood elements of huts one year after construction (Seifert \& Frisvad 2000). It produces fumonisine B1, which may be related to esophageal cancer in humans (Amadi \& Adenyi 2009).

ACKNOWLEDGEMENTS. We thank the anonymous reviewers for constructive remarks and suggestions on the manuscript. Financial support was provided by the W. Szafer Institute of Botany of the Polish Academy of Sciences through its statutory fund, and by the Ministry of Science and Higher Education under Project No. POIR.01.01.01-00-0004/15-00.

\section{REFERENCES}

AJELLO L. 1974. Natural history of dermatophytes and related fungi. Mycopathol. Mycol. Appl. 53: 93-110.

Amadi J. E. \& AdeniYI D. O. 2009. Mycotoxin production by fungi isolated from stored grains. African J. Biotechnol. 8(7): 1219-1221.

Badurowa M. \& BAdura L. 1967. Further investigations on the relationships between soil fungi and the macroflora. Acta Soc. Bot. Poloniae 36: 515-529.

Cano J., Guarro J. \& Figueras M. J. 1987. Some keratinophilic fungi from Spain. Mycopathologia 100: 163-167.

Chlebicki A., Zielenkiewicz U. \& Wilczek A. M. 2014. Fungi are not involved in biofilm formation on rock wall in subterranean arsenic mine in Poland. Nova Hedwigia 99(1-2): 255-269.

Currah R. S. 1985. Taxonomy of the Onygenales: Arthrodermataceae, Gymnoascaceae, Mycotrichaceae and Onygenaceae. Mycotaxon 24: 1-216.

Dematheis F., Kurtz B., Vidal S. \& Smalla K. 2012. Microbial communities associated with the larval gut and eggs of the western corn rootworm. PLOS ONE 7(10): e44685.

DoRENDA M. 1986. Mycoflora as a limiting factor for pathogenic fungi in red clover pure culture and its mixtures with cocksfoot. Acta Mycol. 22: 15-34.

FaterpeKar S. K., Jain S. K. \& Shrivastav A. 2008. Degradation of horse hair by soil inhabiting keratinophilic fungi. Journal of Cell and Tissue Research 8(2): 1471-1476. 
Garg A. P., Gandotra S., Mukerui K. G. \& Pugh G. J. F. 1985. Ecology of keratinophilic fungi. Proc. Indian Acad. Sci. Pl. Sci. 94(2): 149-163.

GŁadoch M. 1978. Beitrag zu Untersuchungen über den Stickstoffumsatz einiger thermophiler und thermotolerant Bodenpilze. Acta Mycol. 14: 157-161.

Guarro J., Gené J., Stichgel A. M. \& Figueras M. J. 2012. Atlas of soil Ascomycetes. CBS-KNAW Fungal Biodiversity Centre, Utrecht, The Netherlands.

GumińsKa B. 1977. The locality of Onygena equina (Willd. ex S.F. Gray) Pers. ex Fr. in the suburbs of Cracow. Zesz. Nauk. Uniw. Jagiellon. Prace Bot. 5: 153-156.

Hansen P. B. 1998. The genus Onygena Pers.: Fr.; species of Ascomycota decomposing keratin. Svampe 37: 19-23 (in Dutch with English summary).

Houbraken J., Visagie C. M., Meijer M., Frisvad J. C., Busby P. E., Pitt J. I., Seifert K. A., Louis-Seize G., Demirel R., Yilmaz N., Jacobs K., Christensen M. \& Samson R. A. 2014. A taxonomic and phylogenetic revision of Penicillium section Aspergilloides. Stud. Mycol. 78: 373-451.

HubÁLEK Z. 2000. Keratinophilic fungi associated with free-living mammals and birds. In: R. K. S. KusHWAHA \& J. GuARro (eds), Biology of dermatophytes and other keratinophilic fungi]. Revista Iberoamericana de Micologia 17: 93-103.

Komorowska H. 1986. Onygena equina (Willd.) Pers. Fr. in Poland. Acta Mycol. 22(1): 49-52.

KozaK E. 2008. Hyphomycets (genera from Ozonium to $\mathrm{Pa}$ pulospora) In: W. MuŁenKo, T. MAJEwsKi \& M. RusZKIEWICZ-MICHALSKA (eds), A preliminary checklist of Micromycetes in Poland, pp. 433-435. W. Szafer Institute of Botany, Polish Academy of Sciences, Kraków.

KuEHN H. H. 1957. Observation on Gymnoascaceae IV. A new species of Arachniotus and a reconsideration of Arachniotus trisporus. Mycologia 49(1): 55-67.

MaŃKa K., PrZezbórski A., KwaŚna H. \& ŻóŁTańsKa E. 1987. Effect of $\mathrm{pH}$ on the activity of some fungi isolated from forest and agricultural sites. Zesz. Probl. Postępów Nauk Roln. 307: 175-196 (in Polish with English summary).

MuŁenko W., Majewski T. \& Ruszkiewicz-Michalska M. 2008. A preliminary checklist of Micromycetes in Poland. W. Szafer Institute of Botany, Polish Academy of Sciences, Kraków.
OtČenašek M. Hudec K., Hubálek Z. \& DvoraK J. 1967. Keratinophilic fungi from the nests of birds in Czechoslovakia. Sabouraudia 5: 350-354.

SCHRÖTER J. 1893. Gymnoascacei (Eidam 1880: Gymnoascen eingeschränkt). In: F. CoHN, Kryptogamen-Flora von Schlesien 3(2): 210-213. J. U. Kern's Verlag, Breslau.

Seifert K. A. \& Frisvad J. C. 2000. Penicillium on solid wood products. In: R. A. SAMSON \& J. I. PITT (eds), Integration of modern taxonomic methods for Penicillium and Aspergillus classification, pp. 285-298. Harwood Academia Publishers, Amsterdam, The Netherlands.

Solé M., Cano J., Stchigel A. M. \& Guarro J. 2002a. Two new species of Auxarthron morphologically and genetically close to A. kuehnii. Stud. Mycol. 47: 103-110.

Solé M., Cano J. \& Guarro J. 2002b. Molecular phylogeny of Amauroascus, Auxarthron, and morphologically similar onygenalean fungi. Mycol Res. 106: 388-396.

SugiYama M., Summerbell R. C. \& Mikawa T. 2002. Molecular phylogeny of onygenalean fungi based on small subunit (SSU) and large subunit (LSU) ribosomal DNA sequences. Stud. Mycol. 47: 5-23.

Świderska-Burek U. \& Mamczarz M. 2008. Penicillium. In: W. Mulenko, T. Majewski \& M. Ruszkiewicz-MiCHALSKA (eds), A preliminary checklist of Micromycetes in Poland, pp. 440-456. W. Szafer Institute of Botany, Polish Academy of Sciences, Kraków.

Uri J, Szathmary S. \& Herpay Z. 1957. Production of an antibiotic by dermatophytes living in horn products. Nature 179:1029-1030.

WAWrzKIEWICZ K, Łobarzewski J. \& Wolski T. 1987. Intracellular keratinase of Trichophyton gallinae. J. Med. Veterin. Mycol. 25: 261-268.

Wright J. M. 1956. Production of gliotoxin in soils. Nature 177: 896 .

Xia J., Huang Z. \& Hu Q. 2013. Histopathological study of Plutella xylostella infected by three entomopathogenic fungal species. Advances in Entomology 1(2): 15-19.

Zimmerman G. 2008. The entomopathogenic fungi Isaria farinosa (formerly Paecilomyces farinosa) and the Isaria fumosorosea species complex (formerly Paecilomyces fumosoroseus): biology, ecology, and use in biological control. Biocontrol Sci. Technol. 18(9): 865-901. 